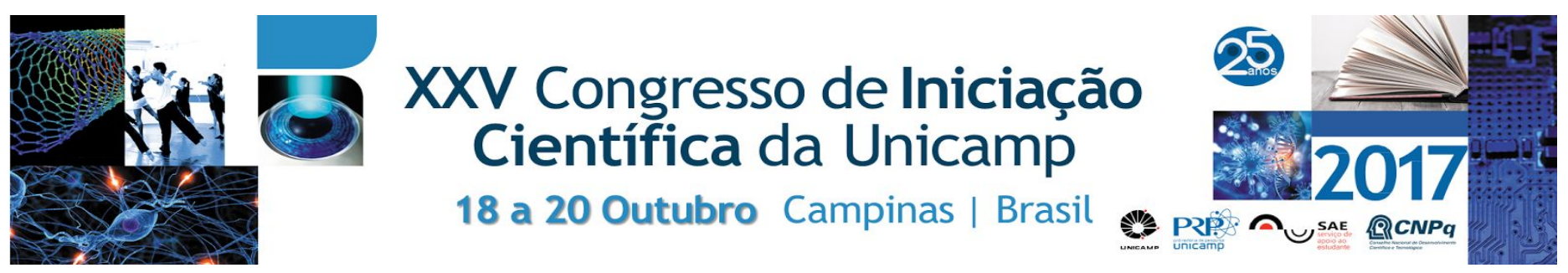

\title{
Relatos de transtornos mentais pelo prisma de indivíduos participantes de um grupo de ajuda mútua
}

\section{Maurício V. Ferreira*, Rosana T. Onocko-Campos}

\section{Resumo}

Há na saúde mental atualmente, a despeito da reforma psiquiátrica, entraves para que ela seja centrada no usuário. Afim de se obter o empoderamento do usuário em saúde mental é necessário que ele desenvolva conhecimento, atitudes e competências para lidar com os problemas advindos do próprio sofrimento ${ }^{1}$, e grupos de ajuda mútua são uma ferramenta importante nesse processo. Neles, os pares participam com suas narrativas sobre seu sofrimento contribuindo para o empoderamento dos usuários. Investigações sobre a efetividade terapêutica desses grupos são fundamentais para contribuir com o aumento do enfoque no usuário no contexto de saúde mental. O objetivo desta pesquisa foi analisar as percepções de usuários participantes de um grupo de ajuda mútua chamado "Ouvidores de Vozes". O material de análise foi coletado em pesquisa prévia do autor, com a utilização do método qualitativo. Tal método envolveu a coleta de informações por meio de uma entrevista semi-dirigida, gravadas com gravador de voz e transcritas na íntegra. Aprofundou-se a análise qualitativa de conteúdo, por meio de leituras flutuantes. As conclusões da pesquisa evidenciaram benefícios do grupo e elucidaram as percepções dos membros sobre autonomia .

\section{Palavras-chave:}

Ajuda mútua, saúde mental, empoderamento.

\section{Introdução}

Grupos de ajuda mútua em que os usuários do sistema de saúde mental compartilhem suas vivências vem sendo uma possibilidade de empoderamento ${ }^{2}$ e utensílio para (re)inserção na sociedade possivelmente melhor do que um tratamento ortodoxo unicamente medicamentoso e estigmatizante. As narrativas de pares proporcionam maior empatia dos usuários, o que estimula uma procura por autoconhecimento. Nesses grupos a sensação de empatia com o grupo pode ter um forte poder na reabilitação e sociabilização, fugindo do estigma em uma sociedade sem pares e aumentando a autonomia do usuário.

Os grupos de ajuda mútua são formados por pares, no sentido de partilharem alguma situação em comum e orientados por uma causa, compartilhando concepções de mundo e valores. Dessa forma, se retoma a tríade dar-receber-retribuir, que aponta que o ato de identificar, compartilhar e fazer circular experiências entre pessoas acometidas por uma mesma condição exerce papel terapêutico ${ }^{3}$.

O objetivo da atual pesquisa é analisar as narrativas de indivíduos participantes do grupo "Ouvidores de Vozes", um grupo de ajuda mútua na área de Saúde Mental na cidade de Campinas e avaliar o impacto e percepção dos usuários a respeito de seu empoderamento e autonomia com a participação no grupo.

\section{Resultados e Discussão}

Visando otimizar a validade de expressão verbal dos entrevistados foi garantido o anonimato utilizando-se o TCLE. A coleta das entrevistas, durante a pesquisa anterior foram aprovadas pelo CEP (CAAE: 55951816.6.0000.5404).
Os relatos dos participantes ilustraram que a realidade de ouvir vozes não configura um adoecimento. O conceito de doença estava sempre associado ao não controle do ouvir vozes, à uma falha no manejo com as vozes. A capacidade de se guiar por sua própria vontade, possuir independência pessoal e o direito de tomar decisões livremente foram itens considerados como autonomia.

\section{Conclusões}

A experiência de compartilhar realidades e histórias de vida proporciona aprendizado. Ao longo das entrevistas realizadas houve grande ênfase no ganho pessoal adquirido com a participação nas reuniões do grupo "Ouvidores de Vozes". Foram ganhos atribuídos ao grupo: o aprimoramento no lidar com as vozes; a superar adversidades; o conforto ao se encontrar com semelhantes atenuando a eventual solidão advinda da sensação de inadequação por ouvir vozes.

\section{Agradecimentos}

Agradeço à Profa. Dra. Rosana T. Onocko-Campos pela liberdade proporcionada e pela paciência. $\mathrm{E}$ ao $\mathrm{CNPq}$ pela oportunidade de dar continuidade à pesquisa. Fomento: CNPq.

1.FARKAS, M; ANTHONY, WA. Psychiatric rehabilitation interventions: a review. Int Rev Psychiatry 2010;22(2):114-129.

2 SERPA JUNIOR, Octavio et al . Experiência, narrativa e conhecimento: a perspectiva do psiquiatra e a do usuário. Physis, Rio de Janeiro, v. 24, Dec2014

3 MAUSS, M. Ensaio sobre a dádiva: forma e razão da troca nas sociedades arcaicas. In: . Sociologia e antropologia. São Paulo: Cosac Naify, 2003. p. 183-294. 